\title{
The influence of geomorphology on the composition of aquatic flora and fauna within a temporary pond network
}

\author{
Margarita Florencio ${ }^{1,4, *}$, Laura Serrano ${ }^{2}$, Patricia Siljestrom ${ }^{3}$, Rocio Fernández-Zamudio ${ }^{1,2}$, \\ Pablo García-Murillo ${ }^{2}$ and Carmen Díaz-Paniagua ${ }^{1}$ \\ ${ }^{1}$ Estación Biológica de Doñana (CSIC), Sevilla, Spain. \\ ${ }^{2}$ Dept. Plant Biology and Ecology, University Sevilla, Sevilla, Spain. \\ ${ }^{3}$ Instituto de Recursos Naturales y Agrobiología (CSIC), Sevilla, Spain. \\ ${ }^{4}$ Present address: Azorean Biodiversity Group (CITA-A) and Platform for Enhancing Ecological Research and \\ Sustainability (PEERS), Departamento de Ciências Agrárias, Universidade dos Açores, Azores, Portugal.
}

* Corresponding author: margarita@ebd.csic.es

Received: 03/03/2014

Accepted: 08/08/2014

\begin{abstract}
The influence of geomorphology on the composition of aquatic flora and fauna within a temporary pond network

Geomorphological and hydrological features can provide a sound basis for global wetland classification. Temporary ponds located on the sandy area of Doñana can be classified into five different geomorphological areas. We hypothesised that these ponds would differ in soil characteristics, which may also explain differences in the composition of their macroinvertebrate, amphibian, and aquatic plant species assemblages. The study ponds were significantly segregated into southern and northern geomorphological areas based on the depth to the water table. The results of the multivariate ordination of soil variables were consistent with a north-south segregation, which was explained by the carbonate and other main ion concentrations in the pond basins. The ponds located in ecotones (marsh-sand and stable-mobile dunes) were particularly rich in amphibians and macroinvertebrates. This result may be explained because the ponds with the longest permanence of water were located in these areas, which represented the only flooded ponds during droughts. In addition, they also contained a high number of temporary ponds, thus favouring connectivity and environmental heterogeneity in these areas.
\end{abstract}

Key words: Temporary ponds, geomorphology, Doñana, aquatic assemblages, macroinvertebrates, amphibians, aquatic plants.

\section{RESUMEN}

Influencia de la geomorfología sobre la composición de la fauna y flora acuáticas de un sistema de lagunas temporales

Las características hidrológicas y geomorfológicas pueden ser de gran utilidad para la clasificación de humedales. Las lagunas temporales del manto eólico de Doñana se pueden clasificar en función de las cinco áreas geomorfológicas en que se encuentran. Nuestra hipótesis se basa en que las lagunas de estas áreas difieren en las características de sus suelos, lo cual puede explicar también las diferente composición de las comunidades de macroinvertebrados, anfibios y plantas que las habitan. Las lagunas del sur de Doñana se diferenciaron de las del norte principalmente en la distancia a la capa freática. Se realizó una ordenación de las lagunas a partir de un análisis multivariante de las características del suelo que resultó consistente con la segregación norte-sur. Se observó una mayor segregación en las comunidades de plantas acuáticas en este gradiente norte-sur, que se explica en función de las concentraciones de carbonatos y de otros iones principales en el suelo de las lagunas. Las lagunas localizadas en áreas de ecotono (marisma-arenas y arenas estabilizadas-arenas móviles) resultaron ser las de mayor riqueza de anfibios y macroinvertebrados. Esto podría deberse a que estas áreas contienen las lagunas de mayor duración, siendo los únicos medios inundados en épocas de sequía, y al alto número de lagunas temporales que presentan, favoreciendo la conectividad y heterogeneidad de ambientes.

Palabras clave: Lagunas temporales, comunidades acuáticas, geomorfología, Doñana, macroinvertebrados, anfibios, plantas acuáticas. 


\section{INTRODUCTION}

The length of the wet phase has long been regarded as a fundamental factor that influences all other features in temporary aquatic systems (Rzóska, 1961). The hydrological regimes of temporary ponds may differ due to many factors such as the pond basin soil, which plays an important role in temporary pond ecosystems. Over long-term periods, an area's inundation frequency and duration affect the physical and chemical processes involved in the development of hydric soils (Rabenhorst, 2004). Hydrogeomorphic-based approaches are preferentially applied in wetland functional assessments (Cole et al., 1997). These approaches are particularly useful in the classification of temporary wetlands in semi-arid regions, where the unpredictability of the climate results in a wide range of hydrological conditions in a single water body between years.

Mediterranean temporary ponds are found in many parts of the world that are characterized by Mediterranean climates. Most of these ponds form in depressions in soils overlying an impermeable substrate and result in a perched water table (Keeley \& Zedler, 1998), as described in California, Chile, South Africa, and western Australia. By contrast, in the Mediterranean basin temporary ponds also occur in floodplains that drain relatively large watershed systems (Keeley $\&$ Zedler, 1998) and are not necessarily associated with impermeable fine sediments. They are common in areas with a Mediterranean climate, in which the desiccation period generally occurs in the summer, and the flooding period follows heavy winter or autumn rainfall (Zedler, 1987; Grillas et al., 2004; Gómez-Rodriguez et al., 2009; Díaz-Paniagua et al., 2010). Despite the worldwide distribution of temporary wetlands, there are few studies addressing the classification of both flora and fauna based on the geomorphological characteristics of their habitats. However, such an approach has been common in wetland plant classifications (Haslam, 2003). The ability of hydrogeomorphic classes to discriminate among other biological communities has been occasionally tested in several wetland areas, with soil organic matter and moisture as the strongest drivers for the typification of macroinvertebrate assemblages (USEPA, 2002). In the Iberian Peninsula, Alonso (1998) developed a typology of crustacean assemblages closely related to substrate, climate and geographic attributes. Recently, Sahuquillo \& Miracle (2013) provided a typology for Mediterranean ponds using crustacean assemblages based on water permanence, climatic and orographic features.

However, pond soil characterisation appears to provide valuable information about the main characteristics of an area, which is related to the composition of aquatic species, and may provide a novel perspective for the classification of aquatic communities.

A large network of temporary ponds is located in Doñana National Park (SW Spain), where more than 3000 ponds may be inundated during years of heavy rainfall (Díaz-Paniagua et al., 2010). These ponds constitute important habitats for amphibians, macroinvertebrates, microcrustaceans, and aquatic vegetation (Díaz-Paniagua et al., 2010). To manage and conserve these habitats, it is of crucial importance to assess their water regime and evaluate the main factors sustaining their wet phase. The several attempts by short-scale studies to classify Doñana ponds into different hydrological categories have produced contradictory results (García-Novo et al., 1991; Bravo \& Montes, 1993; Manzano, 2001). However, the characteristics of the soil of their pond basins could provide a geomorphological framework upon which to base a classification system.

In this study, we analysed the characteristics of the soils of temporary ponds located in the different geomorphological areas of Doñana National Park. We hypothesised that the geomorphological classification of ponds was robust and that ponds in different geomorphological areas would have different compositions of species assemblages (macroinvertebrates, amphibians, and aquatic plants). We were particularly interested in determining if idiosyncratic species were exclusively associated with particular geomorphological areas. 


\section{METHODS}

\section{Geomorphology of the Doñana pond network}

Doñana National Park is a coastal dune area that is located over a large sedimentary aquifer system of approximately $3000 \mathrm{~km}^{2}$. The Doñana region was formed in the Quaternary age when the estuary of the Guadalquivir River was enlarged and reshaped by the formation of sandy spits after the last postglacial transgression (Siljestrom et al., 1994). One half of the park includes an extensive marsh, and the other half is composed of ae- olian sands that form a permeable layer through which waters drain to an unconfined aquifer. The water table is generally shallow in this area and intersects with smooth depressions in the soil surface, forming both permanent and temporary ponds (Manzano \& Custodio, 2006). This aeolian unit has been separated into the following five geomorphological areas that differ in their dynamics, parent material, and age: northern stabilised dunes, southern stabilised dunes, mobile dunes, and two contact areas, or ecotones, which include the peridune ponds and the marsh-dune border (Siljestrom et al, 1994) (Fig. 1).

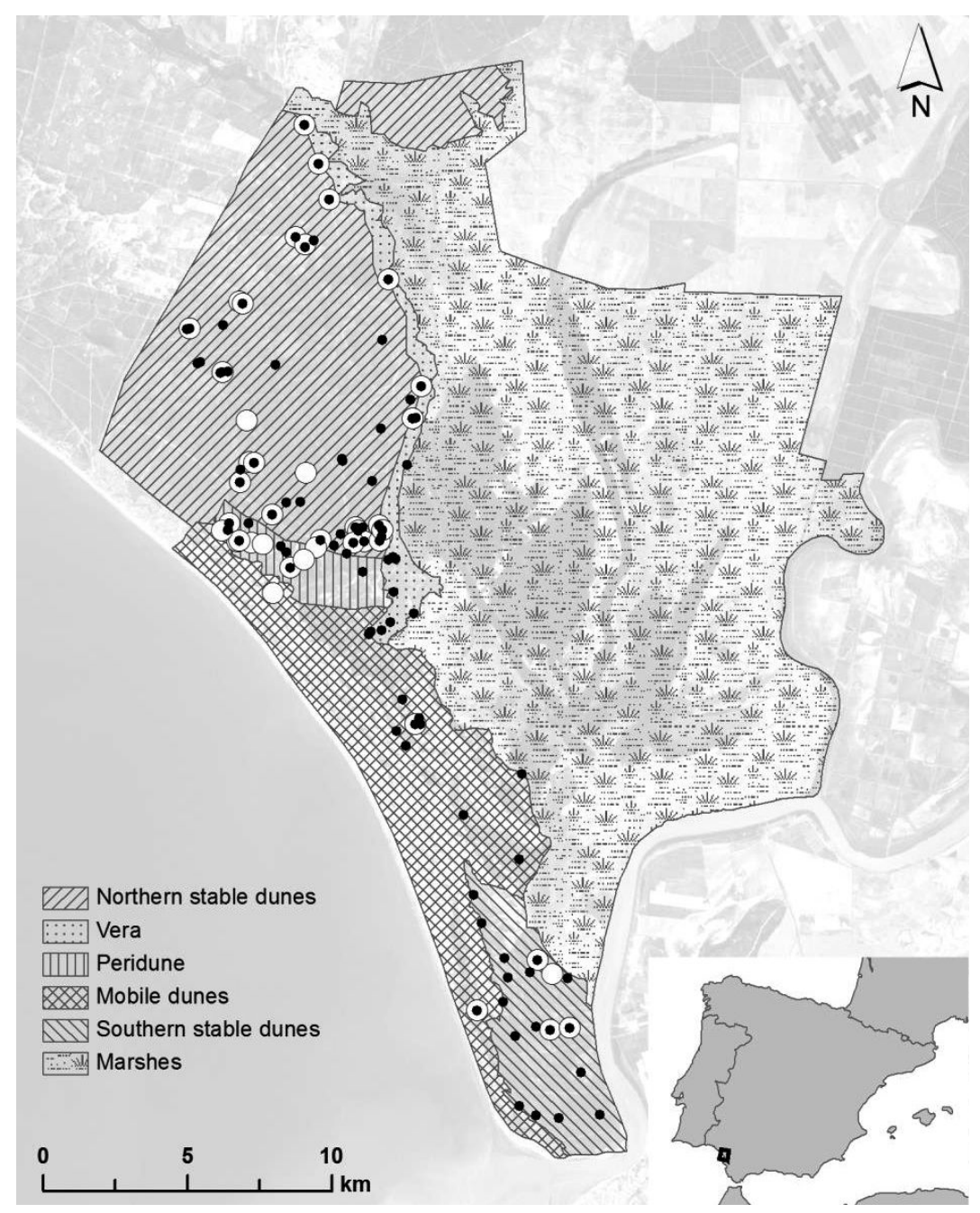

Figure 1. Location of the pond sample soils $(\bigcirc)$ and the flora and fauna pond samples $(\bullet)$ in the five geomorphological areas described for Doñana National Park. Localización de las lagunas muestreadas para el análisis de los suelos (O), y para la determinación de su flora y fauna acuáticas $(\bullet)$ en las cinco áreas geomorfológicas descritas en el Parque Nacional de Doñana. 
The northern stable dune area is an ancient dune system (6000-12000 BP) where temporary ponds form in the lower areas after the rise of the water table by rainfall infiltration. The southern stable dune area, which is of more recent origin (2000-4000 BP), has a smaller extension, and the soils differ in the physico-chemical and mineralogical characteristics (rich in $\mathrm{CaCO}_{3}$ and other salts) from those found in the northern stable dunes, which are mostly siliceous (Siljestrom et al., 1994). In the mobile dunes, discharges from a local dune aquifer form temporary ponds in depressions in interdune valleys (or slacks). The two interfaces between these geomorphological areas play a special role in the formation of ponds because they are characterised by phreatic discharges of groundwater. The peridune ecotone is the area in which mobile dunes and northern stable dunes come in contact. It includes the largest and most permanent ponds of the park that are mainly fed by the dune aquifer. The marsh-stable dune interface is locally known as "La Vera". In this ecotone, the discharges of deep water levels originating from the marsh and stable dunes coincide, often resulting in water running off in shallow and temporary streams after heavy rainfall (Clemente et al., 1998).

Doñana ponds are fed by freshwater (rainfall, runoff, and groundwater discharge) and have no surface or groundwater connection to the sea, although they do receive salts of marine origin through airborne deposition (Serrano et al., 2006). Temporary ponds are flooded after heavy rains, which in this area may occur in autumn, winter, or less frequently, in the spring. The dry phase coincides with summer; it starts in the most ephemeral ponds in the spring, whereas those with the longest hydroperiods (i.e., duration of the flooded period) may retain water until the end of summer (Díaz-Paniagua et al., 2010).

\section{Soil sampling}

To relate the soil geomorphological characteristics of ponds with their aquatic assemblages, soil samples of 43 pond basins located across the five different geomorphological areas were obtained by performing borehole sampling during pond dry periods in $2007(n=34)$ and $2012(n=9)$. We collected samples from each horizon in all profiles for laboratory analyses. Chemical analyses $(\mathrm{pH}$, electrical conductivity, cation exchange capacity (CEC), phosphorus extraction, organic matter characterisation, assimilable cations, and carbonates) were conducted following Sparks \& Bartels (1996). Soil texture was determined using a Boyoucos densimeter (Day, 1986); the percentages of silt and clay were summed to provide the overall percentage of fine sediments. Heavy metals were obtained using humid digestion and

Table 1. Percentages of ponds with different water regimes for which macroinvertebrate, amphibian, and aquatic plant species composition was characterised in 2007. Ponds are categorised into one of the five geomorphological areas described for Doñana National Park. Water regime was classified as follows: temporary ponds (natural temporary ponds with an annual dry phase), excavated ponds (isolated ponds that have been artificially excavated to maintain water in summer), temporary+excavated (temporary ponds that include an excavated pond in their basin to retain water in summer), permanent ponds (large natural ponds that do not dry up in summer) and streams (running waters after heavy rains than then persist as temporary ponds). For amphibians, we sampled an additional pond; the modified percentage is included in brackets. Porcentajes de lagunas con diferente régimen hídrico sobre el total de lagunas en las que se muestraron macroinvertebrados, anfibios y plantas acuáticas en 2007. Las lagunas se han clasificado dentro de cada una de las cinco áreas geomorfológicas descritas en el Parque Nacional de Doñana. En los muestreos se anfibios se muestreó una laguna más que en los otros grupos, por lo que el porcentaje modificado para este grupo se muestra entre paréntesis.

\begin{tabular}{lccccc}
\hline & $\begin{array}{c}\text { Northern } \\
\text { stable dunes }\end{array}$ & $\begin{array}{c}\text { Southern } \\
\text { stable dunes }\end{array}$ & $\begin{array}{c}\text { Mobile } \\
\text { dunes }\end{array}$ & $\begin{array}{c}\text { Peridune } \\
\text { ecotone }\end{array}$ & $\begin{array}{c}\text { La Vera } \\
\text { ecotone }\end{array}$ \\
\hline Temporary ponds & $61.3(62.5)$ & 11.8 & 57.1 & 87.5 & 65.4 \\
Excavated ponds & 19.4 & 88.2 & 42.9 & 0 & 11.5 \\
Temporary+excavated ponds & 19.4 & 0 & 0 & 0 & 0 \\
Permanent ponds & 0 & 0 & 0 & 12.5 & 0 \\
Streams & 0 & 0 & 7 & 8 & 23.1 \\
N ponds sampled & $31(32)$ & 17 & & 26 \\
\hline
\end{tabular}


ICP/OES lectures (Williamson, 1994). To assess the differences in the groundwater levels of the geomorphological areas, we also measured the depth to the groundwater table in the sampled ponds and 36 additional ponds $(n=79$ total sites) throughout the different areas of the park.

\section{Ponds, fauna, and flora}

To relate our data on pond soils to the presence of particular species of aquatic fauna and flora, we used presence/absence data on the vegetation, macroinvertebrates, and amphibians of temporary ponds across the entire park. Data from 89 ponds were collected from March-June 2007 (an additional pond was sampled to gain more information on amphibians: $n=90$ ponds for amphibian data). The ponds' geomorphological locations and water regimes are indicated in Table 1. The water regimes were first classified as follows: temporary, permanent, stream, or artificially excavated. Streams refer to intermittent running waters that only flow towards the marsh after heavy rains and then form lentic ponds. Artificially excavated ponds refer to holes excavated in the deeper parts of natural ponds to reach the phreatic level during dry periods and may be considered as permanent water bodies; they were mainly built to provide water for cattle or wild fauna during the summer (temporary+excavated ponds). These excavated ponds sometimes occupy the entire pond basin, are isolated from natural temporary ponds, and occur mainly in the southern stable dunes.

Amphibians and macroinvertebrates were sampled using a dip-net with a 1-mm mesh size. We performed three successive sweep-nets across a stretch of water of $c .1 .5 \mathrm{~m}$ in each sampling unit to sample the heterogeneous environments mainly based on depth and aquatic plant cover within each pond; we followed the same procedure for both groups of organisms

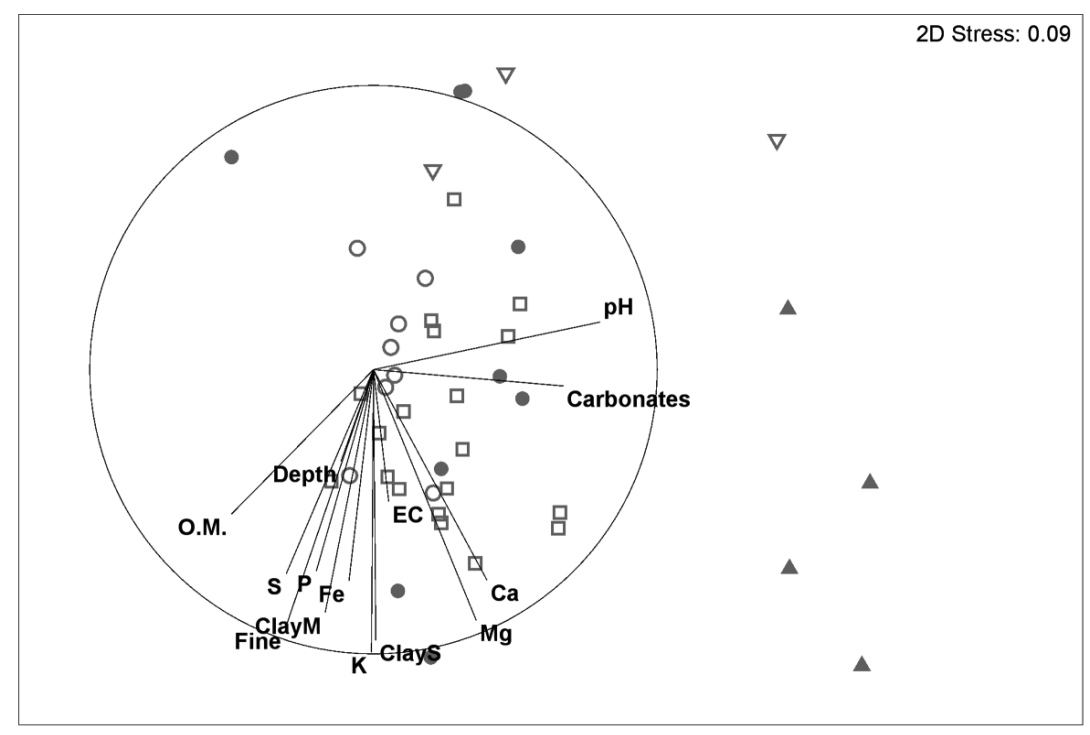

Figure 2. Non-metric multi-dimensional scaling ordination performed on the similarity matrix of pond soil samples according to pond location in the different geomorphological areas of the Doñana aeolian sands: northern stable dunes ( $\square$ ), southern stable dunes

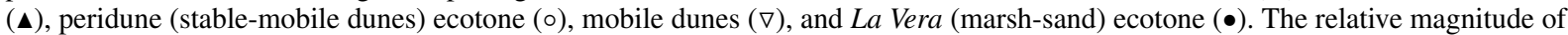
Spearman's correlation values between each soil variable and the pond ordination is indicated by the line size (Depth: phreatic depth; Fine: fine fraction; O.M.: organic matter; EC: electrical conductivity; ClayM: \% of clay in the clay-rich horizon; ClayS: \% of clay in the surface horizon). Ordenación multidimensional no métrica realizada sobre la matriz de similaridad de las muestras de suelo de las lagunas localizadas en las diferentes áreas geomorfológicas descritas en el manto eólico de Doñana: Arenas estabilizadas del norte $(\square)$, arenas estabilizadas del sur ( $\mathbf{\Lambda})$, ecotono peridunar (arenas estabilizadas-dunas móviles (०), dunas móviles ( $\nabla)$, y ecotono de La Vera (marisma-arenas) (•). Se indica la magnitud de los valores de la correlación de Spearman entre los tipos de suelos y la ordenación de las lagunas. (Depth: nivel freático, Fine: fracción fina, O.M.: materia orgánica; EC: conductividad eléctrica, ClayM: $\%$ de arcilla en el horizonte con mayor proporción de arcillas, ClayS: \% de arcillas en el horizonte superficial). 
(see, e.g., Florencio et al. 2009a for a detailed description of the process). Aquatic plants were identified at the same locations. In our analyses, we examined adult and larval macroinvertebrates separately (hereafter referred to as "taxa" for simplicity). Macroinvertebrates were identified to species in the case of most adults or genus in the case of most larvae, although most members of the orders Bassomatophora, Diptera, Haplotaxida, and Lumbricula, as well as of the family Saldidae (Heteroptera), were only identified to the family level. Amphibians and aquatic plants were identified to the species level.

\section{Data analyses}

A multivariate ordination analysis (non-metric MDS) was performed on the similarity matrix of the 14 physico-chemical soil variables using Primer 6.0. These variables were measured in the 43 pond basins that included the deep clayey layer or the topsoil layer when clay was not present. The variables included in this analysis were all $\log$ transformed $(X+1)$, with the exception of the non-transformed $\mathrm{pH}$; electrical conductivity, organic matter content, fine sediments (clay and silt), carbonates, Tot-P, TotCa, $\mathrm{Mg}, \mathrm{S}, \mathrm{Mg}, \mathrm{K}$, and Fe in the surface horizon; clay and total fine sediment contents in the clayrich horizon; and distance to the groundwater table. We then obtained a triangular similarity matrix using Euclidean distances. A multivariate ANOVA analogue (one-way ANOSIM) was used to test for multivariate differences in the soil characteristics of samples from ponds located in different areas, i.e., using the geomorphological areas as grouping factors in the one-way ANOSIM analyses (Primer v6). The ANOSIM statistic $\mathrm{R}$ is close to one when groups are completely different (Clarke \& Warwick, 2001). The ANOSIM analyses also allowed for pair-wise comparisons between the different geomorphological areas. Spearman's rank order correlations were also performed on the untransformed variables. In addition, differences in the depth to the groundwater table among the geomorphological areas were tested using ANOVA and Tukey's post hoc test (STATISTICA 6.0).
Table 2. Pair-wise comparisons obtained after a one-way ANOSIM analysis performed on pond soil variables between the five geomorphological areas (northern: northern stable dunes; southern: southern stable dunes; mobile dunes; peridune: peridune ecotone; and La Vera: La Vera ecotone) indicate significant differences $(p<0.05)$ between the pair-wise comparisons except for two cases $(p>0.1)$; ANOSIM statistic $\mathrm{R}$ is close to one when groups are completely different. Comparaciones pareadas obtenidas en el análisis ANOSIM de una vía sobre las variables del suelo de las lagunas entre las áreas geomorfológicas (Northern: arenas estabilizadas del norte, Southern: arenas estabilizadas del sur, Mobile Dunes: dunas móviles, Peridune: ecotono peridunar y Vera: ecotono de La Vera) indicando diferencias significativas en todas las comparaciones pareadas $(\mathrm{p}<0.05)$ excepto en dos ocasiones $(\mathrm{p}>0.1)$; el estadístico $R$ de ANOSIM se aproxima a 1 cuando los grupos son completamente diferentes.

\begin{tabular}{lcc}
\hline & $\mathrm{R}$ & $p$ \\
\hline Northern $\times$ Southern & 0.99 & 0.0001 \\
Northern $\times$ Mobile Dunes & 0.86 & 0.0006 \\
Northern $\times$ Peridune & 0.12 & 0.11 \\
Northern $\times$ Vera & 0.26 & 0.012 \\
Southern $\times$ Mobile Dunes & 0.85 & 0.029 \\
Southern $\times$ Peridune & 0.99 & 0.002 \\
Southern $\times$ Vera & 0.70 & 0.001 \\
Peridune $\times$ Mobile Dunes & 0.87 & 0.006 \\
Peridune $\times$ Vera & 0.16 & 0.04 \\
Mobile Dunes $\times$ Vera & 0.16 & 0.177 \\
\hline
\end{tabular}

We analysed the similarity in assemblage composition among the sampled ponds using species presence/absence data; separate analyses were performed for amphibians, aquatic plants, and macroinvertebrates. We obtained triangular similarity matrices for each group using the Sørensen similarity coefficient (i.e., the inverse of the Sørensen dissimilarity index). To examine differences in the species compositions of the ponds, we performed three additional one-way ANOSIM analyses using the corresponding triangular similarity matrices of amphibians, aquatic plants and macroinvertebrates; geomorphological area was the grouping factor in all three analyses.

\section{RESULTS}

\section{Pond soil classification}

A non-metric MDS ordination of the 14 pond soil variables showed that differences among the geomorphological areas were mainly attributable to a strong north-south spatial gradient 
Table 3. Exclusive taxa found in particular geomorphological areas in Doñana National Park (presence/absence is indicated as 1/0). The total number of taxa recorded in each area is indicated for each general group (after Florencio et al. 2009a; Díaz-Paniagua et al., 2006; Fernández-Zamudio, 2011). Taxa in bold were found exclusively in a particular area (Adult- A and Larvae- L were different for Coleoptera and Heteroptera; Odonata refers only to aquatic larvae). Taxones que resultaron exclusivos o característicos de lagunas de determinadas áreas geomorfológicas del Parque Nacional de Doñana (la presencia/no detección se indica como 1/0). Se indica el número total de taxa registrados en cada área (según datos de Florencio et al. 2009; Díaz-Paniagua et al. 2006). Se muestran en negritas los taxa exclusivos de un área determinada (se diferencia entre Adultos -A y Larvas -L para Coleoptera y Heteroptera, Odonata se refiere sólo a larvas acuáticas).

\begin{tabular}{ccccc}
\hline & Northern stable & Southern stable & Mobile & Peridune \\
La Vera \\
ecotone & ecotone
\end{tabular}

Amphibians 8

Bufo bufo (Linnaeus, 1758)

Pelodytes ibericus Sánchez-Herráiz,

Barbadillo, Machordom \& Sanchiz, 2000

Coleoptera

Yola bicarinata (Latreille, 1804)-A

Hydaticus leander (Rossi, 1790) -L

Hygrotus inaequalis (Fabricius, 1777) -A

Laccobius revelierei Perris, 1864 -A

Hydrophilus pistaceus (Laporte, 1840) -L

Hydrochara flavipes (Steven, 1808) -L

Limnebius furcatus Baudi, 1872 -A

Gyrinus -L

Heteroptera

Microvelia pygmaea (Dufour, 1833) -A

Odonata

Lestes macrostigma (Eversmann, 1836)

Large Crustaceans

Maghrebestheria maroccana Thiéry, 1988

Cyzicus grubei Simon, 1886

Branchipus cortesi Alonso y Jaume, 1991

Tanymastix stagnalis (Linnaeus, 1758)

Branchipus schafferi Fischer de Waldheim, 1834

Streptocephalus torvicornis (Waga, 1842)

Triops mauritanicus (Ghigi, 1921)

Aquatic Plants

Chara vulgaris $\mathrm{L}$.

Chara fragilis Desv.

Isolepis fluitans (L.) R. Br.

Juncus heterophyllus Dufour

Nitella translucens (Pers.) C. Agardh

Potamogeton natans $\mathbf{L}$.

Lemna trisulca L.

Wolffia arrhiza (L.) Horkel ex Wimmer

Total number of species
0

8

0

42

0

0

0

1

1

0

0

1

18

1

9

0

4

1

0

1

1

1

0

0

65

0

0

1

1

1

1

0

0

146

6

0

0

0

39

1

0

\section{1}

\section{0}

0

0

\section{1}

\section{0}

16

0

7

$$
0
$$

\section{o}

$$
0
$$

$$
0
$$

$$
0
$$

$$
0
$$$$
0
$$

15

$$
1
$$

$$
1
$$$$
0
$$$$
0
$$$$
0
$$$$
0
$$$$
1
$$$$
1
$$

83

6

6

10

10


in carbonates and an east-west gradient in clay (Fig. 2). An ANOSIM analysis showed significant differences between the soil characteristics of the five geomorphological areas (Global $\mathrm{R}=0.46, p=0.0001$ ); all the pair-wise comparisons between these areas were significant $(p<0.05)$, except the comparisons between the peridune ecotone and the northern stable dunes and between La Vera ecotone and the mobile dunes ( $p>0.1$, Table 2).

The pond soils located in the southern stable dunes and the mobile dunes had significantly shallower phreatic depths than the rest of the ponds (ANOVA, $F_{4,73}=8.7128 ; p=0.0001$, and Tukey's test) (Fig. 3). We found larger percentages of excavated ponds in these areas (Table 1), which accounted for the shallower depth of the water table at these sites. Permanent ponds only occurred at sites located in the peridune area (Table 1), together with other extensive ponds with long hydroperiods.

\section{Fauna and flora associated with particular geomorphological areas}

The Doñana pond network provides aquatic habitats for a large number of species of flora and fauna (Table 3). For macroinvertebrates, the highest taxon richness was found in ponds located in the northern stable dunes and La Vera ecotone, with the exception of Odonata, which were richest in the peridune ecotone. We detected idiosyncratic taxa that were exclusively found in particular areas, such as Coleoptera, Odonata and particularly the group of large crustaceans. The highest amphibian species richness was found in the peridune and La Vera ecotones; two species were exclusive to these habitats. The gradient of conductivity largely contributed to a clear differentiation between aquatic plant compositions from the northern (northern stable dunes, Vera and peridune area) and southern areas (mobile dunes and southern stable dunes). The lowest richness of aquatic plants was found in the southern stable dunes and mobile dunes. We did not observe any plant species that exclusively occurred in one particular area, but several species were primarily associated

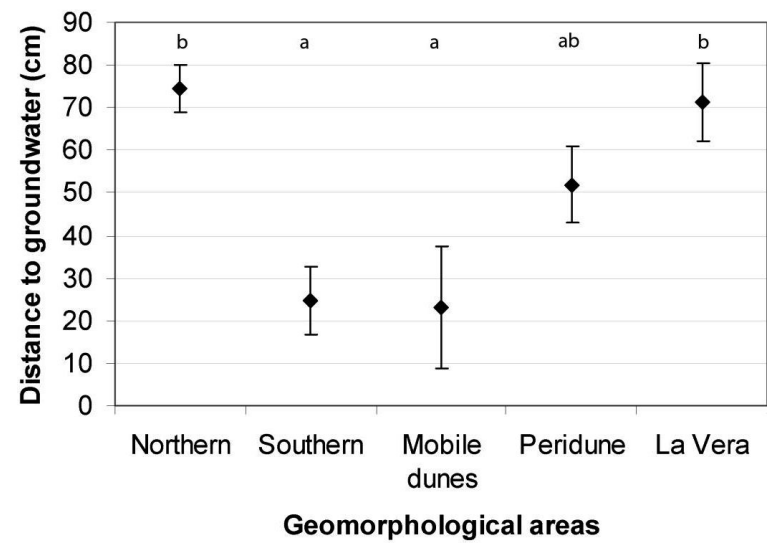

Figure 3. Mean \pm standard deviation of the depth to the groundwater table (phreatic level) of the ponds located in the five geomorphological areas described for Doñana National Park (northern: northern stable dunes; La Vera: La Vera ecotone-contact area between the northern stable dunes and marshes; peridune: peridune ecotone-contact area between the northern stable dunes and mobile dunes; mobile dunes; southern: southern stable dunes). Different letters indicate significant differences after Tukey's post hoc tests for the five geomorphological areas $(p<0.05)$. Media y desviación típica de la distancia a la capa freática de las lagunas localizadas en las cinco áreas geomorfológicas descritas en el Parque Nacional de Doñana (Northern: arenas estabilizadas del norte; La Vera: Ecotono de la Vera-área de contacto entre las arenas estabilizadas del norte y las marismas; Peridune: ecotono peridunarárea de contacto entre las arenas estabilizadas del norte y las dunas móviles; Mobile dunes: Dunas móviles; Southern: Arenas estabilizadas del sur). Las diferentes letras en la figura indican diferencias significativas después de realizar el análisis post hoc de Tukey entre las cinco áreas geomorfológicas $(\mathrm{p}<0.05)$.

with two contiguous areas. Thus, particular plant species only appeared in areas with permanent waters, i.e., in the peridune ecotone that contained permanent ponds and in the southern stable dunes that mainly contained excavated ponds (Table $1 \&$ Table 3 ).

Consequently, ANOSIM analyses revealed that geomorphological areas differed significantly in the composition of their macroinvertebrate (Global $\mathrm{R}=0.12, p=0.0002$ ), amphibian (Global $\mathrm{R}=0.14, p=0.0001$ ), and aquatic plant assemblages (Global $\mathrm{R}=0.33, p=0.0001$ ). Pair-wise comparisons revealed that the assemblage composition of the three organism groups significantly differed $(p<0.05)$ between the mobile dunes and northern stable dunes, northern and southern stable dunes, and southern stable dunes and La Vera ecotone (Table 4). Differences 
Table 4. Pair-wise comparisons obtained after one-way ANOSIM analyses performed for assemblage composition among the five geomorphological areas (northern: northern stable dunes; southern: southern stable dunes; mobile dunes; peridune: peridune ecotone and La Vera: La Vera ecotone). A total of three one-way ANOSIM analyses were performed, one for each biotic assemblage: macroinvertebrates, amphibians, and aquatic plants. Only p-values of significant pair-wise comparisons at $p<0.05$ between the biological assemblages of the geomorphological areas are shown for each group of organisms (ANOSIM statistic R is close to one when groups are completely different; all non-significant pair-wise comparisons at $p>0.06$ ). Comparaciones pareadas obtenidas en los análisis ANOSIM de una vía comparando la composición de las comunidades entre las áreas geomorfológicas (Northern: arenas estabilizadas del norte, Southern: arenas estabilizadas del sur; Mobile Dunes: dunas móviles, Peridune: ecotono peridunar y Vera: ecotono de La Vera). Se realizaron tres análisis ANOSIM de una vía, uno para cada grupo de especies: macroinvertebrados, anfibios y plantas acuáticas. Sólo se muestran los p-valores obtenidos en comparaciones pareadas significativas con $\mathrm{p}<0.05$ entre las composiciones biológicas de las diferentes áreas morfológicas (El estadístico $R$ de ANOSIM se aproxima a 1 cuando los grupos son completamente diferentes; todas las comparaciones pareadas no fueron significativas con un valor de $\mathrm{p}>0.06$ ).

\begin{tabular}{lcc}
\hline & $\mathrm{R}$ & $p$ \\
\hline Macroinvertebrates & & \\
Mobile Dunes $\times$ Northern & 0.21 & 0.05 \\
Mobile Dunes $\times$ Peridune & 0.22 & 0.013 \\
Northern $\times$ Southern & 0.28 & 0.0001 \\
Southern $\times$ Vera & 0.17 & 0.002 \\
Amphibians & & \\
Mobile Dunes $\times$ Northern & 0.31 & 0.015 \\
Northern $\times$ Southern & 0.37 & 0.0001 \\
Northern $\times$ Vera & 0.12 & 0.001 \\
Southern $\times$ Vera & 0.13 & 0.009 \\
Macrophytes & & \\
Mobile Dunes $\times$ Northern & 0.43 & 0.001 \\
Mobile Dunes $\times$ Southern & 0.19 & 0.038 \\
Mobile Dunes $\times$ Vera & 0.21 & 0.041 \\
Northern $\times$ Southern & 0.68 & 0.0001 \\
Northern $\times$ Vera & 0.09 & 0.003 \\
Peridune $\times$ Southern & 0.58 & 0.0001 \\
Southern $\times$ Vera & 0.57 & 0.0001 \\
\hline & & \\
\hline
\end{tabular}

among additional paired areas were also found for macroinvertebrates (1 paired comparison, Table 4), amphibians (1 paired comparison, Table 4) and aquatic plants (4 paired comparisons, Table 4).

\section{DISCUSSION}

The categorisation of ponds according to their geomorphological areas resulted in a useful and robust classification system that revealed important differences in the soil types and assemblages of aquatic flora and fauna. Because wetlands in any region develop according to geomorphological processes that are driven by the interaction of climate and geology (Gilman, 1994), geomorphological and hydrological features can provide a sound basis for a global wetland classification system in which biological variation is independently addressed (Semeniuk \& Semeniuk, 1997). The Doñana wetlands have been traditionally grouped into dune ponds and marshes according to their location. Both types have been further classified by size, hydrological features, and littoral vegetation (as reviewed by Serrano et al., 2006). A quantitative hydro-geomorphological approach established a threshold of $1.6 \mathrm{mS} \mathrm{cm}-1$ to segregate dune ponds from marshes during heavy floods (Espinar \& Serrano, 2009). GarcíaNovo et al. (1991) separated dune ponds into two categories based on the $\mathrm{Na}^{+} / \mathrm{Mg}^{2+}$ ratio of their surface waters, which distinguished groundwater recharge and discharge areas during floods. Further discrimination among ponds has not been achieved, most likely due to the limited amount of information that can be obtained by measuring the concentrations of dissolved or suspended materials under water level regimes that show a high degree of fluctuation (but see Florencio et al., 2009b). By contrast, we used ordination to determine that the patterns of pond soil variables agree with the distribution of the different geomorphological areas located within the Doñana aeolian sands and that the southern stable dune pond soils were segregated from the pond soils in the other areas.

The geomorphological areas differed significantly in the assemblage composition of the main groups of organisms that inhabited their ponds: macroinvertebrates, amphibians, and aquatic plants. We found that the southern stable dunes and mobile dunes in particular had distinct floral and faunal assemblages, likely as a result of the particular features described 
above. Thus, organisms were either distributed along a north-south gradient in electrical conductivity detected in the park (Florencio et al., 2014) or their occurrence was related to specific physico-chemical requirements, as in the case of particular plant species that can only survive in ponds in which water persists for long periods or that have suitable levels of carbonates and salts (Vestergaard \& Sand-Jensen, 2000). Thus, species that required more permanent waters, such as Potamogeton natans L., Lemna trisulca L., or Wolffia arrhiza (L.) Horkel ex Wimmer, were associated with areas where ponds with long hydroperiods are frequent (i.e., peridune ecotone, southern stable dunes and mobile dunes). In the mobile dunes and southern stable dunes, we found characteristic species, such as Chara vulgaris L. and Chara fragilis Desv., that were associated with the characteristically high carbonated and saline waters in these areas, whereas other plant species, such as Isolepis fluitans (L.) R. Br., Juncus heterophyllus Dufour, and Nitella translucens (Pers.) C. Agardh, were associated with low levels of carbonates and salts typically found in the northern stable dunes and the peridune ecotone. It is also important to note that the large branchiopods, which were rare and specifically detected in shallow ephemeral and short-hydroperiod ponds, exhibited low conductivities and water column $\mathrm{P}$ concentrations (Florencio et al., 2013). Particularly, those ponds located in northern stable dunes harboured species with a special biogeographical interest, such as Maghrebestheria maroccana Thiéry, 1988 and Branchipus cortesi Alonso and Jaume, 1991, which suggests the ancient undisturbed origin of these ponds (Sahuquillo \& Miracle, 2013). These ponds mainly differed from ponds located in La Vera ecotone by harbouring particular species in their turbid waters that were associated with fine clay sediment; these areas presented the only records of Triops mauritanicus (Ghigi, 1921), Cyzicus grubei Simon, 1886 and Streptocephalus torvicornis (Waga, 1842) across all the study areas.

The most remarkable feature of the Doñana pond network is its capacity to support wellpreserved communities of flora and fauna. Of the three biotic groups we examined, aquatic plants were the most significantly associated with the pond geomorphological area, most likely due to the plant species' limited mobility and their strong relationships with the substrate (Sculthorpe, 1967). Doñana ponds provide refuge for several species of high conservation status (e.g., W. arrhiza, L. trisulca, Hydrocharis morsus-ranae L., and Caropsis verticillatoinundata (Thore) Rauschert) or with restricted distributions ( $P$. natans and Avellara fistulosa (Brot.) Blanca \& C. Díaz). In the case of animal species, temporary ponds are suitable habitats for specialised aquatic species with complex life cycles and that are vulnerable to the predators typically found in permanent waters (Wellborn $e t$ al., 1996), although predators are not completely absent from these temporary habitats (Fahd et al., 2007). These aquatic habitats are the reproductive sites of many species that do not breed successfully in permanent waters. This is the case for many macroinvertebrates (Collinson et al., 1995; Williams 1997; Céréghino et al., 2008), aquatic plants (Grillas et al., 2004), and amphibian species that are specialised as pond breeders (Semlitsch, 2003). The particular characteristics of the soils found in these areas increased the pond heterogeneity in the park. Thus, in the southern areas of the park, pond persistence mainly depended on the water table fluctuations, and the ponds generally lasted longer. By contrast, in the northern stable dunes and the La Vera ecotone, the less permeable substrate contributed to increased pond density, and pond connectivity favoured an increase in species richness in these areas. The high inter- and intra-annual heterogeneity of Doñana ponds has been reported to sustain the turnover dynamics of amphibian (Gómez-Rodriguez et $a l ., 2010)$ and macroinvertebrate (Florencio et al., 2014) taxa and support the high nestedness of the macroinvertebrate community (Florencio et al., 2011). Every year after the dry summer, macroinvertebrates must recolonise these aquatic habitats from the small number of permanent ponds that have acted as refuges for the adults of many species (Florencio et al., 2011). The traditional management practice of providing 
drinking water for the park's fauna during dry periods, by making existing pond basins deeper or creating new watering holes, has also generated permanent water bodies that support the biodiversity of the entire system and are essential for the conservation of many aquatic plants.

The high degree of dependence of Doñana ponds on the groundwater table should be taken into account by environmental managers. The conservation of these particular habitats should be promoted by the management of groundwater dynamics. Despite Doñana National Park being assigned the highest protection status in Spain, several studies have reported a significant reduction in the length of the aquatic phase of long-hydroperiod ponds over the last decade due to groundwater extraction resulting from urban water use in the nearby tourist resort of Matalascañas (Serrano \& Zunzunegui, 2008; Serrano et al., 2008; Sousa et al., 2009). In general, groundwater overexploitation has been reported in the northern stable dunes and adjacent areas due to improper water management by intensified agriculture in plastic greenhouses (Muñoz-Reinoso, 2001; Manzano \& Custodio, 2006). If the severity of this situation is overlooked, the future of the largest network of temporary ponds in Western Europe will be at risk.

\section{ACKNOWLEDGEMENTS}

This study was funded by the Spanish Ministry of Agriculture, Food and Environment (project 158/2010). We thank Isabel Afán and David Aragonés of LAST_EBD for the map drawing and the management personal of the Parque Nacional de Doñana and the Reserva Biológica de Doñana for their valuable help during our visits to the park.

\section{REFERENCES}

ALONSO, M. 1998. Las lagunas de la España Peninsular. Limnetica, 15: 1-176.

BRAVO, M. A. \& C. MONTES. 1993. Inventario de las formaciones palustres del manto eólico del Par- que Nacional de Doñana (SW España). Actas VI Congreso Español de Limnología: 31-42.

CÉRÉGHINO, R., J. BIGGS, B. OERTLI \& S. DECLERCK. 2008. The ecology of European ponds: defining the characteristics of a neglected freshwater habitat. Hydrobiologia, 597: 1-6.

CLARKE, K. R. \& R. M. WARWICK. 2001. Change in marine communities: an approach to statistical analysis and interpretation, $2^{\text {nd }}$ edition. PRIMERE, Plymouth, UK.

CLEMENTE, L., L. V. GARCÍA, P. SILJESTROM. 1998. Los Suelos del Parque Nacional de Doñana. Technical collection, Ed. O.A. Parques Nacionales, Madrid, Spain.

COLE, A. C., R. P. BROOKS \& D. H. WARDROP. 1997. Wetland hydrology as a function of hydrogeomorphic (HGM) subclass. Wetlands, 17: 456467.

COLLINSON, N. H., J. BIGGS, A. CORFIELD, M. J. HODSON, D. WALKER, M. WHITFIELD \& P. J. WILLIAMS. 1995. Temporary and permanent ponds: an assessment of the effects of drying out on the conservation value of aquatic macroinvertebrate communities. Biological Conservation, 74: 125-133.

DAY, P. R. 1986. Particle Fractionation and Particlesize Analysis. In: Methods of Soil Analysis: Physical and Mineralogical Methods, 2nd edition, Part 1. C. A. Black et al. (eds.): 545-567. Soil Science Society of America Book Series Number 5, American Society of Agronomy, Madison, USA.

DÍAZ-PANIAGUA, C., C. GÓMEZ-RODRÍGUEZ, A. PORTHEAULT\& W. DE VRIES, 2006. Distribución de los anfibios del Parque Nacional de Doñana en función de la densidad y abundancia de los hábitats de reproducción. Revista Española de Herpetología, 20: 17-30.

DÍAZ-PANIAGUA, C., R. FERNÁNDEZ-ZAMUDIO, M. FLORENCIO, P. GARCÍA-MURILLO, C. GÓMEZ-RODRÍGUEZ, A. PORTHEAULT, L. SERRANO \& P. SILJESTROM. 2010. Temporary ponds from the Doñana national park: a system of natural habitats for the preservation of aquatic flora and fauna. Limnetica, 29: 41-58.

ESPINAR, J. L. \& L. SERRANO. 2009. A quantitative hydrogeomorphic approach to the classification of temporary wetlands in the Doñana National Park (SW Spain). Aquatic Ecology, 43: 323-334.

FAHD, K., M. FLORENCIO, C. KELLER \& L. SERRANO. 2007. The effect of the sampling scale on 
zooplankton community assessment and its implications for the conservation of temporary ponds in south-west Spain. Aquatic Conservation: Marine and Freshwater Ecosystems, 17: 175-193.

FERNÁNDEZ-ZAMUDIO, R. 2011. Plantas acuáticas del Parque Nacional de Doñana: aspectos ecológicos y biología de una especie exótica. Ph.D. Thesis, University of Seville (Spain).

FLORENCIO, M., L. SERRANO, C., GÓMEZRODRÍGUEZ, A MILLÁN \& C. DÍAZ-PANIAGUA. 2009a. Inter and intra-annual variation of macroinvertebrate assemblages in temporary ponds from the Doñana National Park (SW Spain). Hydrobiologia, 634: 167-183.

FLORENCIO, M., C. GÓMEZ-RODRÍGUEZ, A. GÓMEZ, M. R., E. GUTIÉRREZ, P. SILJESTROM, L. SERRANO \& C. DÍAZ-PANIAGUA. 2009b. Towards a quantitative classification of temporary ponds in Doñana (SW Spain). In: International Conference on Mediterranean Temporary Ponds. Proceedings \& Abstracts. Fraga, P. (ed.). Consell Insular de Menorca, Maó: 83-92.

FLORENCIO, M., C. DÍAZ-PANIAGUA, L. SERRANO \& D. T. BILTON. 2011. Spatio-temporal nested patterns in macroinvertebrate assemblages across a wide hydroperiod range in a pond network. Oecologia, 166: 469-483.

FLORENCIO, M., C. GÓMEZ-RODRÍGUEZ, L. SERRANO \& C. DÍAZ-PANIAGUA. 2013. Competitive exclusion and habitat segregation in seasonal macroinvertebrate assemblages in temporary ponds. Freshwater Science, 32(2): 650-662.

FLORENCIO, M., C. DÍAZ-PANIAGUA, C. GÓMEZ-RODRÍGUEZ \& L. SERRANO. 2014. Biodiversity patterns in a macroinvertebrate community of a temporary pond network. Insect Conservation and Diversity, 4(7): 4-21.

GARCÍA-NOVO, F., D. GALINDO, J. A. GARCÍA SÁNCHEZ, C. GUISANDO, J. JAÚREGUI, T. LÓPEZ, N. MAZUELOS, J. C. MUÑOZ, L. SERRANO \& J. TOJA. 1991. Tipificación de los ecosistemas acuáticos sobre sustrato arenoso del Parque Nacional de Doñana. Proceedings of III Simposio sobre el Agua en Andalucía, Córdoba, Spain: 165-176.

GILMAN, K. 1994. Hydrology and wetland conservation. Wiley, New York, USA.

GÓMEZ-RODRÍGUEZ, C., C. DÍAZ-PANIAGUA, L. SERRANO, M. FLORENCIO \& A. PORTHEAULT. 2009. Mediterranean temporary ponds as amphibian breeding habitats: the importance of preserving pond networks. Aquatic Ecology, 43: 1179-1191.

GÓMEZ-RODRÍGUEZ, C., C. DÍAZ-PANIAGUA, BUSTAMANTE, J., A. PORTHEAULT \& M. FLORENCIO. 2010. Inter-annual variability in amphibian assemblages: Implications for diversity assesment and conservation in temporary ponds. Aquatic Conservation: Marine and Freshwater Ecosystems, 20: 668-677.

GRILLAS, P., P. GAUTHIER, N. YAVERCOVSKI \& C. PERENNOU. 2004.Mediterranean Temporary Pools, Vol. 1. Issues relating to conservation, functioning and management. Station Biologique de la Tour du Valat, Arles, France.

HASLAM, S. M. 2003. Understanding Wetlands: fen, bog and marsh. London, Taylor and Francis Group. http://dx.doi.org/10.1201/9780203634189

KEELEY, J. E. \& P. H. ZEDLER. 1998. Characterization and Global Distribution of Vernal Pools. In: Ecology, Conservation, and Management of Vernal Pool Ecosystems-Proceedings from a 1996 Conference. C. T. Witham, E.T. Bauder, D. Belk, W. R. Ferren Jr., \& R. Ornduff (eds.): 1-14. California Native Plant Society, Sacramento, USA.

MANZANO, M. 2001. Clasificación de los humedales de Doñana atendiendo a su funcionamiento hidrológico. Hidrogeología y Recursos Hidráulicos XXIV: 57-75.

MANZANO, M. \& E. CUSTODIO. 2006. The Doñana aquifer and its relations with the natural environment. In. Doñana, Water and Biosphere. F. García Novo \& C. Marín Cabrera (eds.): 141150 Spanish Ministry of the Environment, Madrid, Spain.

MUÑOZ-REINOSO, J. C. 2001. Vegetation changes and groundwater abstraction in SW Doñana, Spain. Journal of Hydrology, 242: 197-209.

RABENHORST, M. C. 2004. Pedogenesis of hydric soils- Hydropedology. In: A Guide to Hydric Soils in the Mid-Atlantic Region, ver. 1.0. L. M. Vasilas \& B. L. Vasilas (eds): 21-36. USDA, NRCS, Morgantown, WV, USA. Downloaded at www.epa. gov/reg3esd1/hydric soils/

RZÓSKA, J. 1961. Observations on tropical rainpools and general remarks on temporary waters. Hydrobiologia, 27: 265-286.

SAHUQUILLO, M. \& M. R. MIRACLE. 2013. The role of historic and climatic factors in the distribution of crustacean communities in Iberian Mediterranean ponds. Freshwater Biology, 58: 1251-1266. 
SCULTHORPE, C. D. 1967. The biology of aquatic vascular plants. Edward Arnold Ltd, London, UK.

SEMENIUK, V. \& C. A. SEMENIUK. 1997. A geomorphic approach to global classification of natural inland wetlands and rationalization of the system used by the Ramsar Convention-a discussion. Wetlands Ecology and Management, 5: 145-158.

SEMLITSCH, R. D. 2003. Amphibian Conservation. Smithsonian Books, Washington, USA and London, UK.

SERRANO, L., M. M. REINA, G. MARTIN, I. REYES \& A. ARECHEDERRA. 2006. The Aquatic Systems of Doñana (SW Spain): Watersheds and Frontiers. Limnetica, 25: 11-32.

SERRANO, L. \& M. ZUNZUNEGUI. 2008. The relevance of preserving temporary ponds during drought: hydrological and vegetation changes over a 16-year period in the Doñana National Park (south-west Spain). Aquatic Conservation: Marine and Freshwater Ecosystems, 18: 261-279.

SERRANO, L., M. P. ESQUIVIAS-SEGURA \& M. ZUNZUNEGUI. 2008. Long-term hydrological changes over a seventeen-year period in temporary ponds of the Doñana N. P. (SW Spain). Limnetica, 27: 65-78.

SOUSA, A., P. GARCÍA-MURILLO, J. MORALES, J. \& L. GARCÍA-BARRÓN. 2009. Anthropogenic and Natural Effects on the Coastal Lagoons in the Southwest of Spain (Doñana National Park). Ices Journal of Marine Science, 66: 1508-1514.

SILJESTROM, P., A. MORENO, L. V. GARCÍA
\& L. CLEMENTE. 1994. Doñana National Park (SW Spain): Geomorphological characterization through a soil-vegetation study. Journal of Arid Environments, 26: 315-323.

SPARKS, D. L. \& BARTELS, J. M. 1996. Methods of Soil Analysis: Chemical Methods. Part 3, Soil Science Society of America Book Series, Soil Science Society of Agronomy, Inc., Madison, USA.

USEPA. 2002. Methods for Evaluating Wetland Condition \#7 Wetlands Classification. EPA-822-R-02017. http://www2.epa.gov/sites/production/files/ documents/wetlands_7classification.pdf

VESTERGAARD, O. \& K. SAND-JENSEN. 2000. Alkalinity and trophic state regulate aquatic plant distribution in Danish lakes. Aquatic Botany, 67: 85-107.

WELLBORN, G., D. K. SKELLY \& E. E. WERNER. 1996. Mechanisms creating community structure across a freshwater habitat gradient. Annual Review of Ecology and Systematics, 27: 337-363.

WILLIAMS, D. D. 1997. Temporary ponds and their invertebrate communities. Aquatic Conservation: Marine and Freshwater Ecosystems, 7: 105-117.

WILLIAMSON, A. D. 1994. Supplement to Standard Measurement Protocols, Florida Radon Research Program, EPA/600/R-94/001. U.S. Environmental Protection Agency, Air and Energy, Research Triangle Park, NC, USA.

ZEDLER, P. H. 1987. The ecology of southern California vernal pools: a community profile. U.S. Fish and Wildlife Service, Biology Report 85(7.11). 